\title{
Floods of record
}

\author{
Chris Paola
}

\section{Research on two Bolivian rivers provides explanations of how and when they flood. It also gives pointers for interpreting Earth's history as recorded by the sediments left behind by flood waters.}

$\mathrm{O}$ ne of the quirks of the Earth's stratigraphic recording system is that it operates in fits and starts, archiving surface conditions for a while and then suddenly switching off. The sedimentary 'record' button is evidently pretty finicky. It is sensitive to external controls, but also to the internal dynamics of the sediment-deposition system. An intriguing example of how the recording process works is given on page 493 of this issue. Aalto et al. ${ }^{1}$ show how changes in the way that rainwater is delivered to a river system, driven by the El Niño/Southern Oscillation (ENSO) climate cycle in the Pacific Ocean, can switch one of the major processes of sedimentation on and off.

River flooding seems a fairly straightforward process — so much so that one could easily overlook the fact that no obvious natural law decrees how often and by what means a river should flood, or, for that matter, that it should flood at all. An alluvial river channel (one formed from its own sediment) and its adjoining flood plain are self-formed from the interplay of water, sediment and vegetation. The dynamics of flooding results from the way in which the channel-flood-plain system organizes itself. In many alluvial rivers, sedimentation associated with flooding creates 'natural levees', low ridges that run along the edges of the channel. These levees are naturally formed counterparts of the familiar artificial levees built to control flooding in populated areas. They raise the 'overtopping' threshold of the channel and in so doing create a pressure-head that helps drive water onto the flood plain once the levee is breached. So, rather than gradually inundating the flood plain, water can enter as a relatively focused, narrow flow that often carries with it a good deal of suspended sediment. Once the flow leaves the breach (the 'crevasse'), it expands and dumps its load in the form of a fan, colourfully referred to as a crevasse splay. The deposits of these fans fill much of the flood plain around the main channel with distinctive sheets, usually of sand or silt ${ }^{2-5}$.

An interesting twist concerns the effects of clear water (also referred to as black water) on the flood plain. Clear water can come directly from rainfall, or it can be channelderived water that has deposited its charge of

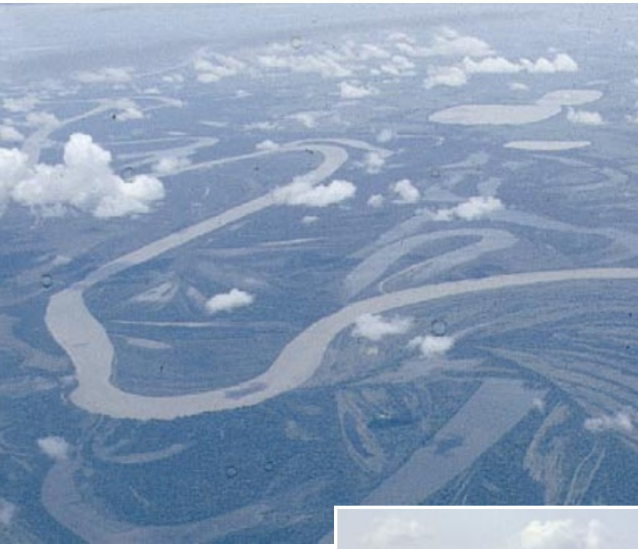

Figure 1 River features. The Mamore river in flood, with (inset) an example of a nascent natural levee, formed from sediment, that grows to ine the river channel.

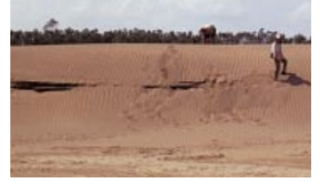

does not explain their data. They argue instead for a more subtle and interesting explanation: the controlling variable is not the size of the flood, but how quickly it rises, because of the clear-water effect outlined above. Slow rises allow time for clear water to pool on the flood plain, and the resulting back-pressure counters that of the main flood wave. With reduced pressure on the levee, there are fewer levee breaches and hence fewer splay deposits.

Aalto et al. stress the implications of their findings for our understanding of how climate cycles control the sequestration of sediment - along with associated nutrients and carbon - in river flood plains. But their work has a further significance. The stop-and-go nature of sedimentation leads to pervasive discontinuity in the stratigraphic record ${ }^{7}$. Time is missing from sedimentary sequences on all scales (imagine what it would be like if you remembered only one year of each

sediment elsewhere. In either case, if the flood plain is inundated with clear water, and if the channel flood wave rises slowly enough, the water pooled on the flood plain produces back-pressure that works with the levee system to contain the channel flow. This back-pressure becomes more effective as the flood plain becomes higher. In addition, inundating the flood plain with clear, particle-free water inhibits sedimentation there, instead sending the sediment on downriver ${ }^{6}$

Aalto et al. ${ }^{1}$ take these ideas forward. They show how clear-water effects, along with ENSO-related variability in rainfall delivery, turn flood-plain sedimentation on and off in two rivers, the Beni and the Mamore (Fig. 1). These rivers rise in the Bolivian Andes and run eastwards into the Amazon basin, depositing large amounts of sediment in a major topographical depression (the Andean foreland) as they go. Through a combination of coring, oceanographic-style data collection over a broad area of the river basin and a new ${ }^{210} \mathrm{~Pb}$ dating technique, Aalto et al. show that crevasse-splay deposits in these rivers are clustered temporally, and that these clusters are associated with cold (La Niña) phases of the ENSO climate cycle.

One might think of explaining the clustering of flood-plain depositional events in terms of higher flood levels, but the authors find that flood magnitude alone decade, and of that year, only one of every ten days, and so on). This discontinuity gives recorded planetary (geological) time a different architecture to human time - fractal as opposed to continuous ${ }^{8}$.

It is easiest to measure stratigraphic discontinuity at the extremes. On short timescales (seconds to days), it can be constrained by observations of sedimentary structures, and on long timescales (typically 100,000 years and above) by rock-dating techniques. The processes that lead to discontinuity at scales between these limits are much less well understood. Aalto and colleagues' work provides one of the bestdocumented examples of the role that climate variability, which is thought to be strong over these intermediate timescales, could play in controlling the Earth's temperamental 'record' button.

Chris Paola is in the Department of Geology and Geophysics, and St Anthony Falls Laboratory,

University of Minnesota, Minneapolis,

Minnesota 55414, USA.

e-mail:cpaola@umn.edu

1. Aalto, R. et al. Nature 425, 493-497 (2003).

2. Aslan, A. \& Autin, W. J. J. Sedim. Res. 69, 800-815 (1999)

3. Blum, M. D. \& Törnqvist, T. Sedimentology 47 (suppl. 1), 2-48 (2000)

4. Slingerland, R. \& Smith, N. D. Geology 26, 435-438 (1998)

5. Smith, N. D., Cross, T. A., Dufficy, J. P. \& Clough, S. R. Sedimentology 36, 1-23 (1989).

6. Mertes, L. A. K. Wat. Resour. Res. 33, 1749-1762 (1997).

7. Sadler, P. M. J. Geol. 89, 569-584 (1981).

8. Plotnick, R. J. Geol. 94, 885-890 (1986). 